\title{
Indian Education - Global Relevance
}

\author{
V. T. Shailashri ${ }^{1}$ \& Surekha Shenoy ${ }^{2}$ \\ ${ }^{1}$ Research scholar, Srinivas Institute of Management Studies, Srinivas University, \\ Mangalore -575001, INDIA. \\ ${ }^{2}$ Srinivas Institute of Management Studies, Srinivas University, \\ Mangalore - 575001, India \\ E-mail: shailavt@yahoo.co.in
}

Type of the Paper: Research Analysis.

Type of Review: Peer Reviewed.

Indexed In: OpenAIRE

DOI: http://dx.doi.org/10.5281/zenodo.1133687.

Google Scholar Citation: IJCSBE

\section{How to Cite this Paper:}

Shailashri, V.T., \& Shenoy, Surekha. (2017). Indian Education-Global Relevance. International Journal of Case Studies in Business, IT and Education (IJCSBE), 1(2), 93-102.

DOI: http://dx.doi.org/10.5281/zenodo.1133687.

International Journal of Case Studies in Business, IT and Education (IJCSBE)

A Refereed International Journal of Srinivas University, India.

(C) With Authors.

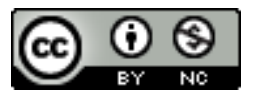

This work is licensed under a Creative Commons Attribution-Non Commercial 4.0 International License subject to proper citation to the publication source of the work.

Disclaimer: The scholarly papers as reviewed and published by the Srinivas Publications (S.P.), India are the views and opinions of their respective authors and are not the views or opinions of the S.P. The S.P. disclaims of any harm or loss caused due to the published content to any party. 


\title{
Indian Education - Global Relevance
}

\author{
V. T. Shailashri ${ }^{1}$ \& Surekha Shenoy ${ }^{2}$ \\ ${ }^{1}$ Research scholar, Srinivas Institute of Management Studies, Srinivas University, \\ Mangalore -575001, INDIA. \\ ${ }^{2}$ Srinivas Institute of Management Studies, Srinivas University, \\ Mangalore - 575001, India \\ E-mail: shailavt@yahoo.co.in
}

\begin{abstract}
The global economy has undergone a structural transformation: there will be a workforce of 3.3 billion needed by 2020, in the services and capital-intensive manufacturing sectors. This phenomenon is expected to play out in India - by 2020. 90\% of India's GDP and $75 \%$ of employment is expected to be obtained from the services and manufacturing sectors. Technological advancement shall have several jobs redundant while also creating new job roles. The structural shift in generating employment will increase demand for sophisticated workers, innovators, and thinkers who could thrive in globally-connected and a dynamic economy. India, with a large workforce and an increasing pool of educated graduates, is in a strategic position to reap the benefits of this shift. However, the 'demographic divided' will likely be squandered unless India can create a "globally relevant and competitive" higher education system that serves the requirements of both the domestic as well as global economy. India is prominently placed on the global higher education map in terms of more globally-reputed Indian institutions, significant student and faculty mobility, presence of collaborations with quality international institutions India as a hub for talent that is able to drive competitiveness of the Indian economy and is fit to work in or serve international markets This paper is an attempt to identify the needs of global competitiveness in the Indian students. Secondary data is used in depth to identify the shift needed in higher education.
\end{abstract}

Keywords: Indian Education system, Global competiveness, Strategic positioning, Current system employability.

\section{INTRODUCTION :}

The global economy is undergoing structural transformation which requires a workforce of 3.3 billion by 2020, in the services and capital intensive-manufacturing sectors. The phenomena is also expected to play out in India - by $2020,90 \%$ of India's GDP and $75 \%$ of employment is expected to be contributed by the services and manufacturing sectors. Technological advancement will make many jobs redundant while creating new job roles. This shift in employment will increase demand for sophisticated workers, innovators, and thinkers who will thrive in a globally-connected and dynamic economy. India, with its large workforce and increasing higher education graduates, is strategically positioned to reap the benefits of this shift. However, the 'demographic divided' will be squandered unless [1] India is able to create a "globally relevant and competitive" higher education system that serves the requirements of both the domestic as well as global economy.

- Low employability of graduates, driven by several factors including outdated curricula, shortage of quality faculty, high student-teacher ratios, lack of institutional and industry linkages, and lack of autonomy to introduce new and innovative courses.

- Low impact research output and patents filed given relatively low government and corporate spending on research, insufficient doctoral students [2], missing research focus and culture in most institutions, and lack of international research collaborations 
- Limited focus on entrepreneurship on campus as reflected in the fact that there are few institutes that offer programs in entrepreneurship and have active incubation / entrepreneurship cells [3].

- Complex regulatory requirements and hurdles, poor institutional governance standards, and lack of professional management [4].

\section{LITERATURE REVIEW :}

Researchers believe that learning style is a good predictor of an individual's preferred learning behavior (Bostrom, Olfman and Sein, 1993 [5]). Lindsay (1999) [6] found that a match between learning style and teaching style reveals increases in student achievement and satisfaction. Contrary to these findings, Hajizainuddin (1999) [7] found no significant relationship between the informationprocessing characteristics of learning style and performance. In addition, he found no significant interaction among the factors of learning style, hypermedia's organizational structure and attitude. Desai (1996) [8] indicated that learning style does not significantly influence a subject's learning .While there is plenty of study done on learning styles, there does not seem to be any agreement or approval of any one theory (Bruen and Conlan, 2002) [9]. Furthermore, not all researchers and writers agree with learning style models. A research report from the Learning and Skills Research Center (Coffield et al., 2004) [10] studied many influential learning style models and did a critique of all experimental learning style theories. This research questions the reliability, validity and implication of learning styles in general. In addition, the authors have criticized some of the research that has used these models including the Kolb's learning style model and disagreed with the way they came to their conclusions. According to the paper, Kolb's Learning Style Inventory (LSI) in general 'should not be used for individual selection'. Referring to the validity and reliability of LSI the paper indicated that 'the construct validity of the LSI has been challenged and there is a long public dispute over reliability of LSI'. Furthermore, the paper indicated that, there is no proof that 'matching' increase educational performance in future education and that the findings are inconsistent and questionable. Markham (2004) [11] points out that the research on learning style has to go further than the simplistic effort to show that people differ on a measure and that these differences lead to a definable learning outcome.

Several classifications of learning style and related concepts have been developed through the years. These classifications include Solomon's Inventory of Learning Styles, the Meyers-Briggs Type Indicator, Howard Gardner's multiple intelligences, McCarthy's 4-Mat system, and Honey and Mumford's (1986) [12] social approach to learning. Perhaps the most widely known approach to assessing learning style, however, is that of David Kolb (1984) [13].

According to Kolb (1984) [13] individuals learn in four stages or modes: concrete experience, reflective observation, abstract conceptualization, and active experimentation. However, in different learning situations individuals often use different combinations of learning modes; hence no one mode clearly identifies an individual's learning style. The combination of learning modes forms four quadrants reflecting four learning styles: Accommodator, Diverger, Assimilator, and Converger.

As indicated above, there is a need to accommodate different learning styles and modes. This accommodation requires more than recognizing the students' learning styles, however. Not only does learning style and mode vary by individual, but teaching style varies as well. Ebeling (2000) [14] suggests that there is evidence most instructors use a teaching style that is comfortable to them and this is often the way they themselves learn best. According to Taylor (1998) [15] all instructors need to be able to address a variety of learning styles and Kay (1998) [16] proposes communication is improved by understanding how people learn. There is research to support varying teaching style to match learning style. Roach et al. (1993) [16] examined alternative teaching styles in marketing classes. Filbeck and Smith (1996) [17] looked at both teaching and learning styles along with age and gender. Borg and Shapiro (1996) studied teaching styles in economics classes. Hayes and Allinson (1996) [18] analyzed 19 studies, which examined matching learning style to learning method and found support in improved learning performance. There are also many research results on quality in teaching-learning processes in higher education system [19-58].

\section{THE OBJECTIVES OF THE STUDY :}

- To identify parameters for globally relevant and competitive Higher education system. 
- To understand the Indian higher education system in the same context.

- To evaluate the Indian Higher education system with respect to the performance indicators.

\section{METHODOLOGY :}

The study is purely based on secondary data. Relevant authentic sources have been used to draw a generic conclusion. Graphical representations are also based on the secondary data. Apart from the secondary sources, in-depth focus group interview was conducted with experts in the area to arrive at conclusions.

\section{DISCUSSIONS :}

\subsection{Basically there are three types of institutions [Diagrammatic representation below]}

* Institutions offering a wide range of courses aimed at providing a well-rounded and holistic education to India's masses and imparting skills that are relevant to the local industry/community.

* Institutions offering technical/professional courses, with a focus on producing industry-ready graduates.

\$ High-quality institutions with research and innovation as the prime focus.

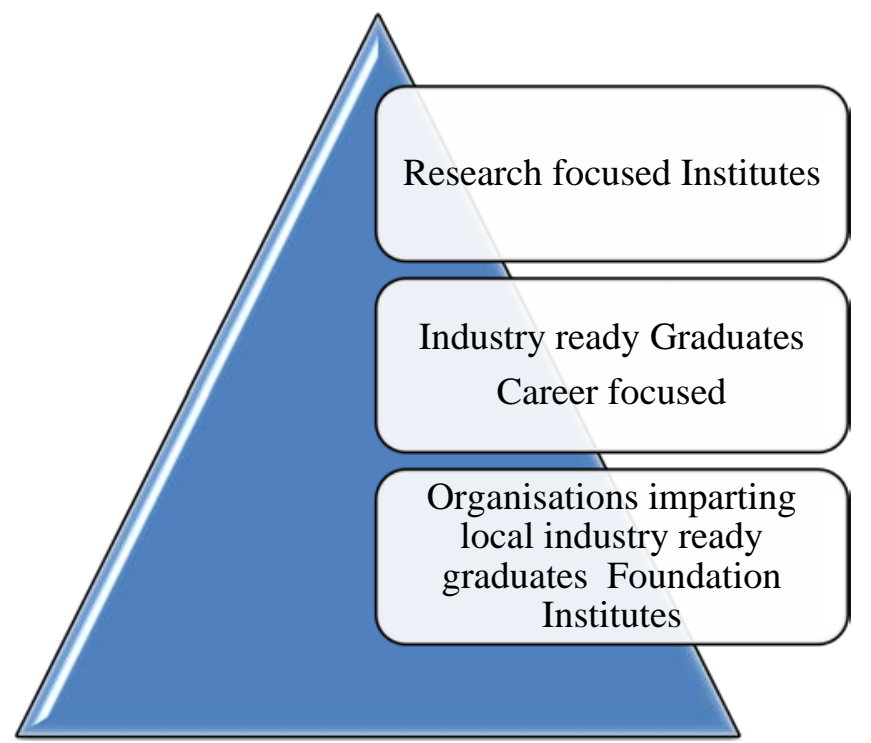

Fig. 1: Three types of institutions in India

The above diagrammatic representation shows that in India there is more number of foundation courses institutions and the number of research oriented institutions is lesser in number. The study reveals that there are a number of institutions which are more focused on a holistic education and India should move towards the first two tiers in the Pyramid.

\subsection{India prominently placed on the global higher education map:}

Globally reputed Indian institutions: Indian institutions amongst the best in the world. India has a number of well acknowledged institutions. The standards are high. The approach to learning is different and students enjoy learning in these institutes.

The study of the secondary data revealed the parameters include

* India prominently placed on the global higher education map.

\# India as a hub for talent.

* Inculcation of a culture of research, innovation, and entrepreneurship that can power high economic growth in the country.

India prominently placed on the global higher education map:

Mobility of International students and faculty: There is mobility of students and teachers on a fulltime basis as well as through student and faculty exchange, twinning arrangements, etc. India has a 
large number of foreign students from Third world developing countries coming. The syllabus and orientation to certain courses is gaining importance.

Transnational education: Indian institutions with foreign campuses and global institutes with campuses in India. India is opening doors to foreign education. We see a number of collaborations and tie-ups with foreign institutions.

Deep collaborations between Indian and foreign HEIs: The number of collaborations is increasing year on year.

India as a hub for talent, that is able to drive competitiveness of the Indian economy and meet the needs of international markets:

- Highly employable graduates that can drive the global competitiveness of India's economy.

- Globally fit workforce: Graduates who can participate in international labor markets.

Inculcation of a culture of research, innovation, and entrepreneurship that can power high economic growth in the country:

- Knowledge creation leading to the development of innovative products, services, and business models.

- A conducive entrepreneurial ecosystem to incubate new ideas and businesses that can power economic growth and job creation.

The manpower required is going to increase and India has a skillful employee able workforce. India has the potential to meet the future needs of the world. By 2020 the aging workforce is going to increase and India alone can supply around 47 Million employees. Therefore India's demographic advantage will spread across the globe. Countries like US, China, Japan, Russia, and UK have a population crunch. There is going to be a huge shortage of employable workforce. Brazil, Mexico, and India have a skillful workforce. The below graph is an indicator of the same.

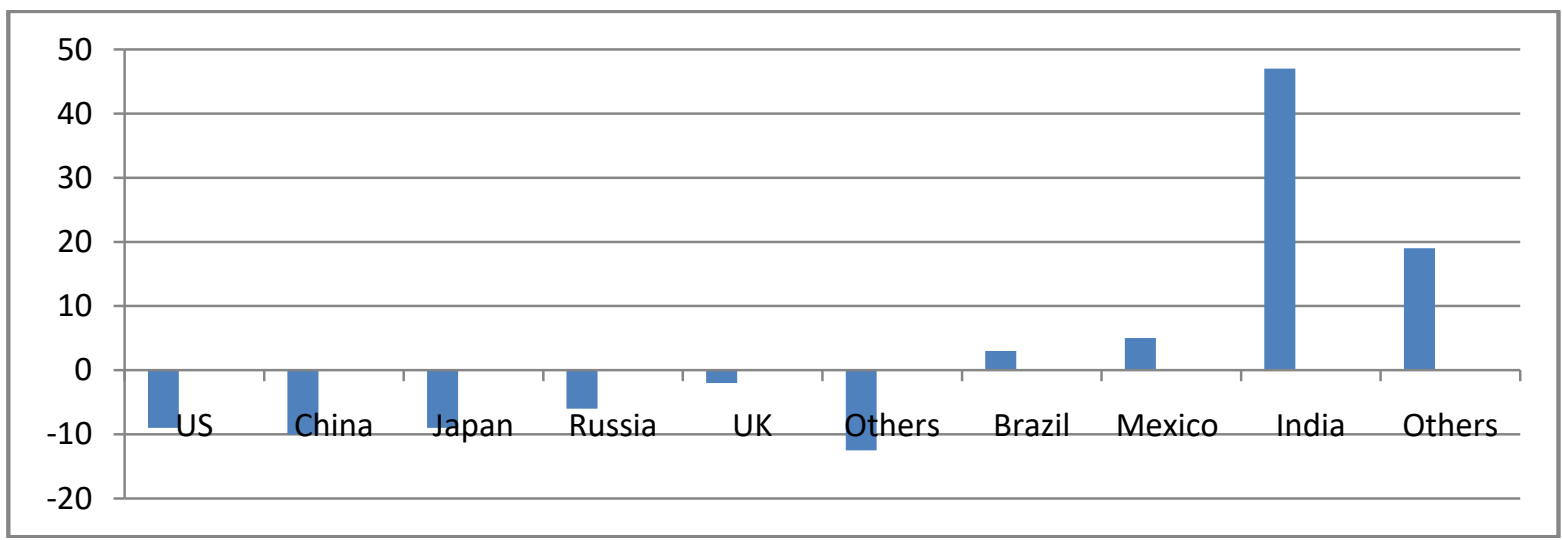

Fig. 2: Indian Potential employment in Percentage

The below graph (Fig. 3) reveals that India has a weak standing in terms of Academic reputation and Employee reputation. In terms of Faculty student ratio citations and international student ratio and staff ratio we need to meet the world Standards. But when we compare this to other developed countries India has a weak standing. 


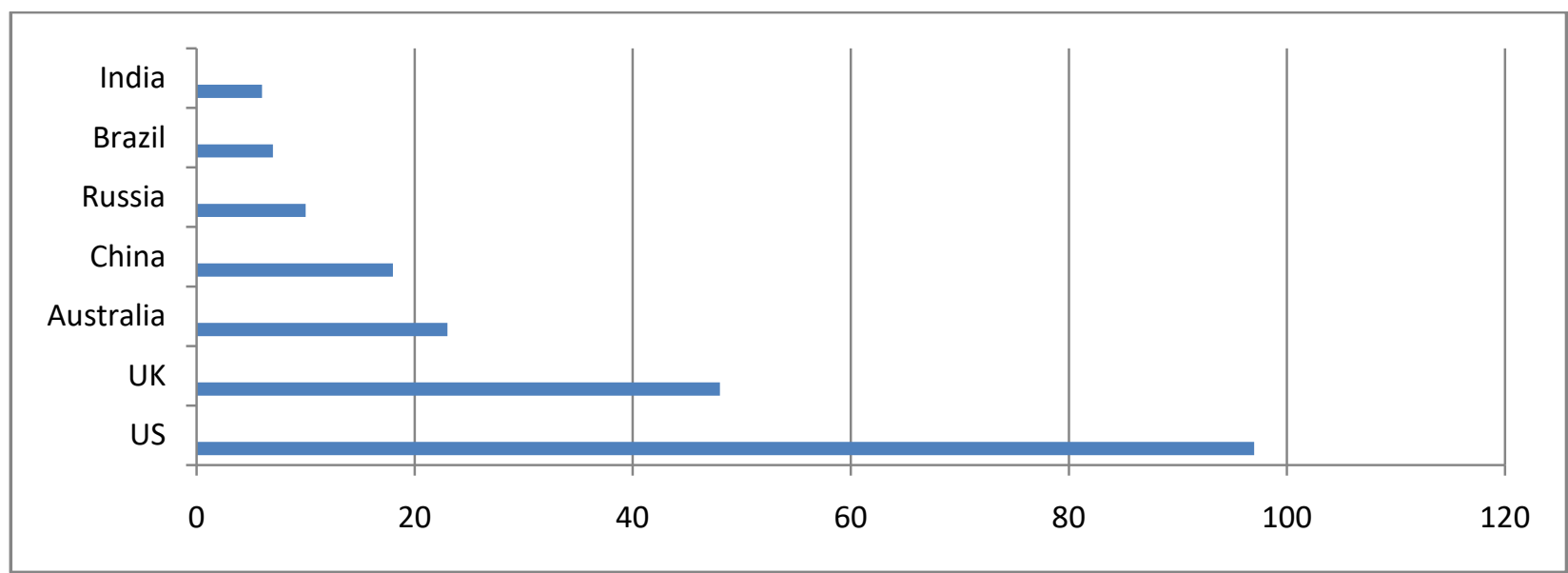

Fig. 3: India’s Academic Reputation in Percentage

5.4 India prominently placed on the global higher education map :

Table 1: India prominently placed on the global higher education map

\begin{tabular}{|c|c|}
\hline Performance indicators & Potential root causes \\
\hline $\begin{array}{l}\text { - Very few globally recognized HEI } \\
\text { - High outbound student mobility to } \\
\text { developed countries and inbound } \\
\text { mobility from emerging markets } \\
\text { - Low number of Indian campuses } \\
\text { abroad } \\
\text { - Limited quality international tie ups }\end{array}$ & $\begin{array}{ll}\text { - } & \text { Limited focus on research and innovation } \\
\text { - } & \text { Low brand recognition of Indian HEI } \\
\text { - } & \text { Low perception of Indian higher education } \\
& \text { Restive and complex regulation }\end{array}$ \\
\hline
\end{tabular}

The above table shows the potential performance indicators in India include very few globally recognized Higher education institutes, more of outbound student's lower number of Indian campuses abroad and limited international tie -ups. The reasons for these problems lie because of limited research, low brand image rigid regulations and low perception of India Higher Education.

\subsection{India as a hub for talent:}

Table 2: India as a hub for talent

\begin{tabular}{|c|c|}
\hline Performance indicators & Potential root causes \\
\hline $\begin{array}{l}\text { - Large pool of unemployable graduates } \\
\text { - Substantial discrepancy in salaries } \\
\text { between top tier HEIs and lower rung } \\
\text { ones. } \\
\text { - International migration of labor mainly to } \\
\text { Gulf Cooperation Countries (GCC) } \\
\text { primarily for low- end jobs }\end{array}$ & $\begin{array}{l}\text { - Graduates lacking basic employability skills } \\
\text { including soft skills, critical thinking skills, } \\
\text { etc. } \\
\text { - } \text { Outdated curricula. } \\
\text { - High student-faculty ratio and shortage of } \\
\text { highly qualified faculty. } \\
\text { - Very few industry-academia linkages at } \\
\text { program level; industry participation limited } \\
\text { to placement. }\end{array}$ \\
\hline
\end{tabular}

The above table reveals for India to be a talent hub the problems faced are India has a large pool of graduates who are unemployable and the student faculty ratio is less and India does not have strong industry -academia linkage

5.6 Culture of innovation research and entrepreneurship:

Table 3: Culture of innovation research and entrepreneurship

\begin{tabular}{|c|c|}
\hline Performance indicators & Potential root causes \\
\hline $\begin{array}{l}\text { - Increasing number of research } \\
\text { publications but with low impact [11]. }\end{array}$ & $\begin{array}{l}\text { - Low doctoral education capacity. } \\
\text { - Inadequate government funding; funding }\end{array}$ \\
\hline
\end{tabular}


- Growing number of patents filed, but meager when compared to China and the US.

- Limited number of start-ups. skewed towards central institutions.

- HEIs do not have meritocratic access to government funding.

- Limited international research collaborations Incubation centers are limited in number that too in top institutions.

The above table reveals that India has a low doctoral education capacity and needs to have adequate funding and international collaborations.

\section{CONCLUSION :}

The study examines the current state of the system through the lens of "global relevance and competitiveness" and identified impediments that are hindering progress. Subsequently, it can further propose measures that key stakeholders, i.e. Government, industry and institutions, could take to make the Indian higher education system truly globally relevant and competitive. The study attempted to identify the problems faced by the Indian higher education system and is an attempt to rectify the problems. Thus Indian education is marching towards meeting world standards. The learning methods need to identify interesting tools to enhance employability.

\section{REFERENCES :}

[1] Bostrom, R. P., Olfman, L. and Sein, M. K. (1993). Learning styles and end-user training: A first step, MIS Quarterly, 17(3), 118-120.

[2] Bruen, C. and Conlan, O. (2002). Adoptive ICT support for learning styles - A development framework for re-usable learning resources for different learning styles \& requirements, ITTE 2002 annual conference of the association of information technology for teacher education. 2545.

[3] Canavan, J. (2004). Personalized e-learning through learning style aware adaptive systems, Published dissertation, University of Dublin, pp. 135-139.

[4] Chang, C. C. (2001). Construction and evaluation of a web-based learning portfolio system: An electronic assessment tool, Innovation in Educations \& Training International, 38(2), 144-145.

[5] Ghosh, S.C. (1989), Education Policy in India since Warren Hastings, Naya Prakasan, Calcutta, 23-26.

[6] Rao, D. Pulla (2003). Progress of Elementary Education in Vishakhapatnam district, A.P. Journal of AIAER, 15(3\&4), 18-25.

[7] Ayar, R.V. Vaidhyanathan (2005). What lesson can DPEP offer. Journal of educational planning and administration, 19(1), 49-65.

[8] Government of India (2005), Manual for Planning and Appraisal, Sarva Shiksha Abhiyan, Department of Elementary Education and Literacy, MHRD, New Delhi, pp. 45-58.

[9] Government of India (2006), Elementary Education in India, Progress toward UEE, National University of Educational Planning and Administration, New Delhi, pp. 10-45.

[10] Government of India (2007), Elementary Education in India, Progress toward UEE, National University of Educational Planning and Administration, New Delhi, pp.10-45.

[11] Government of India (2008), Elementary Education in India, Progress toward UEE, National University of Educational Planning and Administration, New Delhi, pp 12-30.

[12] Keay, F.E. (1980). Ancient Indian Education: Origin, Development and Ideals, Cosmo Publications, New Delhi, pp. 40-147.

[13] Government of India (2010), The Gazette of India, Eighty Sixth Amendment Act, 2002, Ministry of Human Resource Development, Department of School Education and Literacy, New Delhi. 
[14] Garcia-coll, C. Akiba, D., Palacios, N., Baileg, B., Silver. R., Dimartino, L., Chin, C. (2002). Parental involvement in children's education: (144) lessons from three immigrant groups. Science and Prentice, 2 (3), 303-334.

[15] Meriam, L., Brown, R., Cloud, H., Dale, E., Duke, E., Edwards, H., et al. (1928). The Problem of Indian Administration. Baltimore, MD: Johns Hopkins Press, pp. 56-58.

[16] Organizational psychology: A book of readings, Englewood Cliffs, NJ: Prentice of Educational Planning and Administration, New Delhi, pp. 27-42.

[17] Rrash S. and Nassibeh J (2011). Estimation of custom dissatisfaction based on service quality gaps by correlation and regression analysis in a Travel Agency, International Journal of business and management, 6(3), 17-19.

[18] Sravanan, S. (2002). Enrichment of commerce education through accounting research' University News, 40(19), 10-12.

[19] Aithal, P. S. \& Suresh Kumar, P. M. (2017). Challenges and Opportunities for Research \& Publications in Higher Education. International Journal of Scientific Research and Modern Education (IJSRME), 2(1), 42-49. DOI: http://dx.doi.org/10.5281/ZENODO.400619.

[20] Krishna Prasad, K \& Aithal, P. S. (2017). A Study on Online Education Model using Location Based Adaptive Mobile Learning. International Journal of Applied Engineering \& Management Letters, 1(1), 36-44. DOI: http://dx.doi.org/10.5281/zenodo.820457.

[21] Sridhar Acharya, P. \& Aithal, P. S., (2017). Transformation of Knowledge in Teaching Learning Environment Adoption of Innovative Methodology in Teaching Software Engineering. International Journal of Case Studies in Business, IT and Education (IJCSBE), 1(2), 22-28. DOI: http://dx.doi.org/10.5281/zenodo.846649.

[22] Aithal, P. S. Shailashree, V. T. \& Suresh Kumar, P. M. (2016). ABCD analysis of Stage Model in Higher Education. International Journal of Management, IT and Engineering (IJMIE), 6(1), 11-24. DOI : http://doi.org/10.5281/zenodo.154233.

[23] Aithal, P. S. \& Priti Jeevan, (2016). Strategic Rethinking of Management Education : Green MBA Model. International Journal of Management, IT and Engineering (IJMIE), 6(1), 55-73. DOI : http://doi.org/10.5281/zenodo.154278.

[24] Aithal, P. S. (2016). Creating Innovators through setting up organizational Vision, Mission and Core Values : a Strategic Model in Higher Education. International Journal of Management, IT and Engineering (IJMIE), 6(1), 310-324. DOI : http://doi.org/10.5281/zenodo.161147.

[25] Aithal, P. S. \& Shubhrajyotsna Aithal, (2016). Impact of On-line Education on Higher Education System. International Journal of Engineering Research and Modern Education (IJERME), 1(1), 225-235. DOI : http://doi.org/10.5281/zenodo.161113.

[26] Aithal, P. S. \& Jeevan Pinto, (2016). Innovations in Higher Education - A new model implemented in MCA degree programme of Srinivas University. International Journal of Scientific Research and Modern Education (IJSRME), 1(1), 275-289. DOI : http://doi.org/10.5281/zenodo.161107.

[27] Sridhar Acharya, P. \& Aithal, P. S. (2016). Environmental Consciousness in Higher Educational Institutions : A case of SIMS, International Journal of Current Research and Modern Education (IJCRME), 1(1), 273-284. DOI : http://doi.org/10.5281/zenodo.161083.

[28] Aithal, P. S. \& Suresh Kumar, P.M. (2016). Analysis of Choice Based Credit System in Higher Education. International Journal of Engineering Research and Modern Education (IJERME), 1(1), 278-284. DOI : http://doi.org/10.5281/zenodo.161046.

[29] Aithal, P. S. (2016). Innovations in Student Centric Learning - A Study of Top Business Schools in India. International Journal of Engineering Research and Modern Education (IJERME), 1(1), 298-306. DOI : http://doi.org/10.5281/zenodo.161045. 
[30] Aithal, P. S. (2016). Innovations in Experimental Learning - A Study of World Top Business Schools. International Journal of Scientific Research and Modern Education (IJSRME), 1(1), 360-375. DOI : http://doi.org/10.5281/zenodo.161043.

[31] Aithal, P. S. (2016). How to Increase Research Productivity in Higher Educational Institutions SIMS Model. International Journal of Scientific Research and Modern Education (IJSRME), 1(1), 447-458. DOI : http://doi.org/10.5281/zenodo.161037.

[32] Aithal, P. S., \& P. M. Suresh Kumar, (2016). Teaching - Learning Process in Higher Education Institutions. International Journal of Multidisciplinary Research and Modern Education (IJMRME), 2(1), 662-676. DOI : http://doi.org/10.5281/zenodo.160956.

[33] Aithal, P. S., \& P. M. Suresh Kumar, (2016). Maintaining Teacher Quality in Higher Education Institutions, International Journal of Current Research and Modern Education (IJCRME), 1(1), 701-711. DOI : http://doi.org/10.5281/zenodo.160946.

[34] Aithal, P. S., and P. M. Suresh Kumar. (2016). Student performance and Learning Outcomes in Higher Education Institutions. International Journal of Scientific Research and Modern Education (IJSRME), 1(1), 674 - 684. DOI : http://doi.org/10.5281/zenodo.160944.

[35] Aithal, P. S., \& P. M. Suresh Kumar, (2016). Catering Student Enrollment and Retaining Diversity in Higher Education Institutions. International Journal of Engineering Research and Modern Education (IJERME), 1(1), 565 - 577. DOI : http://doi.org/10.5281/zenodo.160939.

[36] Aithal, P. S. \& P. M. Suresh Kumar, (2016). Student Evaluation and Reforms in Higher Education Institutions. International Journal of Multidisciplinary Research and Modern Education (IJMRME), 2(1), 652-661. DOI : http://doi.org/10.5281/zenodo.160932.

[37] Prithi Rao, and Aithal, P. S. (2016). Green Education Concepts \& Strategies in Higher Education Model. International Journal of Scientific Research and Modern Education (IJSRME), 1(1), 793-802. DOI : http://doi.org/10.5281/zenodo.160877.

[38] Aithal, P. S. (2016). Student Centric Curriculum Design and Implementation - Challenges \& Opportunities in Business Management \& IT Education. IRA International Journal of Education and Multidisciplinary Studies, 4(3), 423-437. DOI : http://dx.doi.org/10.21013/jems.v4.n3.p9.

[39] Shubrajyotsna Aithal \& Aithal, P. S., (2016). Student Centric Learning Through Planned Hardwork - An Innovative Model. International Journal of Scientific Research and Modern Education (IJSRME), 1(1), 886-898. DOI: http://doi.org/10.5281/zenodo.61830.

[40] Aithal, P. S. \& Shubhrajyotsna Aithal (2016). Ekalavya Model of Higher Education - an Innovation of IBM's Big Data University. International Journal of Current Research and Modern Education (IJCRME), 1(2), 190-205. DOI: http://dx.doi.org/10.5281/ZENODO.198704.

[41] Srinivas Rao, A., Suresh Kumar, \& Aithal, P. S., (2015). Strategic Planning in Higher Education Institutions : A Case Study of SIMS - VISION 2025. International Journal of Educational Science and Research, 5(2), 29-42. DOI: http://doi.org/10.5281/zenodo.61589.

[42] Aithal, P. S., Srinivas Rao, A. \& Suresh Kumar, P.M. (2015). How Innovations and Best Practices can Transform Higher Education Institutions : A case study of SIMS. International Journal of Management (IJM), 6(2), 83 - 98. DOI: http://doi.org/10.5281/zenodo.61594.

[43] Aithal, P. S., (2015). Teaching through Entry Test \& Summarization - An Effective Classroom Teaching Model in Higher Education Training. International Journal of Scientific Research and Education, 3(3), 3022 - 3027. DOI : http://doi.org/10.5281/zenodo.61637.

[44] Reshma \& Aithal, P. S. (2015). Quality Enhancement in Office Management of Higher Education Institutions through Innovations \& Best Practices. International Research Journal of Business \& Management, 8(5), 16 - 27. DOI: http://doi.org/10.5281/zenodo.61638. 
[45] Aithal, P. S. \& P.M. Suresh Kumar, (2015). Enhancement of Graduate attributes in Higher Education Institutions through Stage Models. IMPACT: International Journal of Research in Business Management, 3(3), 121 - 130. DOI : http://doi.org/10.5281/zenodo.61640.

[46] Aithal, P. S., \& Shubhrajyotsna Aithal, (2015). An Innovative Education Model to realize Ideal Education System. International Journal of Scientific Research and Management (IJSRM), 3(3), 2464 - 2469. DOI: http://doi.org/10.5281/zenodo.61654.

[47] Aithal, P. S., Srinivas Rao, A \& Suresh Kumar, P. M. (2015). Quality Enhancement in Higher Education Institutions : A case study of SIMS. International Journal of Multidisciplinary Research and Development, 2(5), 18-31. DOI: http://doi.org/10.5281/zenodo.266940.

[48] Aithal, P. S., (2015). How an Effective Leadership and Governance Supports to Achieve Institutional Vision, Mission, and Objectives. International Journal of Multidisciplinary Research and Development, 2(5), 154-161. DOI: http://doi.org/10.5281/zenodo.266788.

[49] Aithal, P. S., (2015). Internal Quality Assurance Cell and its Contribution to Quality Improvement in Higher Education Institutions : A Case of SIMS. GE International Journal of Management Research (IJMR), 3(5), 70-83. DOI: http://doi.org/10.5281/zenodo.266808.

[50] Aithal, P. S., (2015). Development and Deployment in Higher Education Institutions. Elixir International Journal, 84, 33594 - 33597. DOI: http://doi.org/10.5281/zenodo.266779.

[51] Aithal, P. S., (2015). Strategies to be adopted in Higher Education Institutions to Enhance Admission Demand. International Journal of Extensive Research, 5, 9-25. DOI: http://doi.org/10.5281/zenodo.268530.

[52] Aithal, P. S., (2015). Faculty Empowerment Strategies in Higher Education Institutions. International Journal of Management, IT and Engineering (IJMIE), 5(7), 108-115. DOI: http://doi.org/10.5281/zenodo.266967.

[53] Aithal, P. S., (2015). MBA++ as a Unique \& Successful Model in Integrated Development of Business Executives. International Journal of Management, IT and Engineering (IJMIE), 5(7), 124-133. DOI: http://doi.org/10.5281/zenodo.266987.

[54] Aithal, P. S., and P. M. Suresh Kumar, (2015). Applying SWOC Analysis to an Institution of Higher Education. International Journal of Management, IT and Engineering (IJMIE), 5(7), 231-247. DOI : http://doi.org/10.5281/zenodo.163425.

[55] Institutional Aithal, P. S., Suresh Kumar, P. M. and Deekshitha, (2015). Societal Expectation and Accountability in Higher Education. International Journal of Management, IT and Engineering (IJMIE), 5(7), 361-373. DOI : http://doi.org/10.5281/zenodo.267021.

[56] Aithal, P. S., Suresh Kumar, P. M., and Pavithra Kumari, (2015). Methods and Approaches for Employability Skill Generation in Higher Educational Institutions. International Journal of Management, IT and Engineering (IJMIE), 5(7), 390-410. DOI: http://doi.org/10.5281/zenodo.267044.

[57] Aithal, P. S., and P. Harischandra, (2015). Quality Enhancement in Higher Education Institutions through Best Practices in Library: A Case of SIMS. International Journal of Management, IT and Engineering (IJMIE), 5(7), 489-505. DOI: http://doi.org/10.5281/zenodo.268518.

[58] Pradeep M.D, and Aithal, P. S., (2015). Learning through Team Centric Exercise \& Key Point Pedagogy - An effective Learning Model for Slow Learners in Higher Education Training. International Journal of Multidisciplinary Research \& Development, 2(9), 265-270. DOI: http://doi.org/10.5281/zenodo.267765. 